\title{
Determinant of Rainfed and Dry Seasons Rice Farming in Ayamelum Local Government Area of Anambra State, Nigeria
}

\author{
Obianefo Chukwujekwu Aloysius, Anarah Emeka Samuel, Osuafor Ogonna Olive, \\ Anumudu Oluchi Odinaka
}

Department of Agricultural Economics and Extension, Nnamdi Azikiwe University, Awka, Nigeria

Email address:

obianefoca@gmail.com (O. C. Aloysius)

\section{To cite this article:}

Obianefo Chukwujekwu Aloysius, Anarah Emeka Samuel, Osuafor Ogonna Olive, Anumudu Oluchi Odinaka. Determinant of Rainfed and Dry Seasons Rice Farming in Ayamelum Local Government Area of Anambra State, Nigeria. Agriculture, Forestry and Fisheries.

Vol. 9, No. 2, 2019, pp. 33-38. doi: 10.11648/j.aff.20200902.13

Received: December 1, 2019; Accepted: December 16, 2019; Published: May 18, 2020

\begin{abstract}
The study on the determinant of rain-fed and dry season rice farming in Ayamelum Local Government Area of Anambra State, Nigeria estimated the production function of rice farmers at rain-fed, as well as at dry season. The study equally looked at the challenges confronting rice farmers in the study area at both season. A well-structured questionnaire as well as face to face interview were the research instruments used to elicit information from randomly selected 100 ( 70 rain-fed and 30 dry seasons) rice farmers for the study. A combination of analytical tools were utilized, multiple regression and principal factor analysis were the research models used to operationalize the study concept. The regression result with the highest significant variables as well as the highest coefficient of multiple determinant (R2) were chosen as the lead equation, while each challenges confronting rice farmers at both season in the study area were named according to the factors with the highest loading. The study found out that the R2 for both rain-fed and dry season rice farming was 0.8951 and 0.7999 respectively. These confirms that the error beyond the control of the farmers at rain-fed was $10.5 \%$ and $20.0 \%$ at dry season. The study equally revealed that the determinants of rain-fed rice farming were fertilizer $\left(\beta=0.484\right.$ and $\left.t=5.11^{* *}\right)$, urea $(\beta=$ 0.661 and $\left.\mathrm{t}=4.43^{* *}\right)$, agro-chemical $\left(\beta=27.488\right.$ and $\left.\mathrm{t}=4.65^{* *}\right)$ and labour $\left(\beta=28.008\right.$ and $\left.\mathrm{t}=4.42^{* *}\right)$. While labour supply $\left(\beta=39.425\right.$ and $\left.\mathrm{t}=16.09^{* *}\right)$ and farm size $\left(\beta=250.344\right.$ and $\left.\mathrm{t}=4.19^{* *}\right)$ were the determinants of dry season rice farming in the study area. Environmental factor accounted for $21.42 \%$ and $21.79 \%$ of the variance of factors challenging rice farming at rain-fed and dry season respectively. Institutional factor accounted for $15.34 \%$ and $17.90 \%$ of the variance of factors challenging rice farming at rain-fed and dry season respectively, and Economic accounted for $13.51 \%$ and $14.37 \%$ of the variance of factors challenging rice farming at rain-fed and dry season respectively. The three factors explained $50.28 \%$ and $54.06 \%$ of the variance of the factors challenging rice farming at both season in Ayamelum Local Government Area.
\end{abstract}

Keywords: Rain-fed, Dry Season, Production Function, Food Basket, Significant, Factors

\section{Introduction}

Rice is one of the fastest growing staples in the food basket of many families in Nigeria, its production is a major source of employment, income generation and nutrition in many poor food in-secure households in Nigeria and the world at large $[1,2]$. Farmers can still undertake rice farming under rain-fed and irrigated system as a quick way of generating income in the agricultural sector [3]. Nigeria has been reported as the nineteenth largest producer of rice in the world, surpassed in Africa by Egypt and Madagascar [4]. Notwithstanding this fact, the Central Bank of Nigeria $(\mathrm{CBN})$ assert that Nigeria is the largest importer of rice in Africa [5].

Rice is grown in four different environments in Nigeria as classified into rain-fed upland, rain-fed lowland, irrigated lowland and mangrove swamp [6]. Only $15 \%$ of the total land area (1.8 million hectares) available for cereals cultivation in Nigeria is utilized by rice farmers [7]. Also, the most important land area (mangrove swamp) for rice farming 
accounted for less than $1 \%$ of the land area used by rice farmers in Nigeria. Equally, irrigated system (large scale and small scale irrigation scheme) accounted for $16 \%$, rain-fed upland system accounted for $30 \%$, while, rain-fed lowland system accounted for $53 \%$ of the land used by rice farmers [1].

Nigeria has not been able to keep up with the annual rice demand and supply ratio. As at December ending 2018, the annual rice demand growth rate in Nigeria was $7.8 \%$ and the supply growth rate was $5.5 \%$ leaving a deficit demandsupply gap of $2.3 \%$ [8, 9 and 10]. Despite several government support programs like IFAD assisted Value Chain Development Programme (VCDP), Fadama III Additional Financing, and Agricultural Transformation Agenda Special Programme (ATASP-1), Anambra State, on the other hand, was unable to meet up with the State annual rice demand of 320,000 metric tons (MT). Only 210,000 MT against the 320,000 MT required to sustain her populace in 2018 was produced [11]. This suggests that rice farming for both main season and dry season (irrigated) is the only option to shift production upward [12], but considering the technological requirements for all year round rice farming, there is a need for rice farmers in Nigeria to not rely on their traditional experience [9]. On the part of the farmers gain, many researchers concluded that dry season rice farming is more profitable, so apart from making more food available the farmers are equally making more money $[13,14]$.

A number of factors have been identified to be the reason behind the inability to meet up with rice demands in Nigeria, these factors were; low productivity, inefficiency in resource allocation, little or no access to improved variety, and production in the hand of small scale out-growers who rely heavily on traditional technology, low level of income, high cost of inputs, poor access to irrigation facilities, pest and diseases that reduce yield, and high cost of labour. [15, 16]. This, therefore, makes it more rewarding for the researcher to identify those factors (farm size, labour use, access to irrigation facilities) that are major determinant both season rice farming [12, 17]. Age, household size, level of education, access and size of credit, farming experience, contact with extension agents among others have been reported as the determinant of dry season rice farming in Nigeria [18, 19 and 20]. These determinants are the farmer's socioeconomic status that mount pressure on rice production as the experience requirement need skills for all year round production [21]. Thus, to achieve sustainability in this rice demand and supply gap, there is the need to train rice farmers on the capacity of labour supply, input utilization as well as other management function that will bring about increase in productivity [22].

Objective

The main aim of this study is to find out the determinants of rain-fed and dry season rice farming in Ayamelum Local Government Area of Anambra State. Thus, the study specifically tends to:

i. estimate the production function of rain-fed and dry season rice farmers, and ii. find out the challenges faced by rice farmers at different seasons in the study area.

\section{Research Methodology}

The Study Area

The study was carried out in Ayamelum Local Government Area (L. G. A), Anambra State. Anaku is the head-quarter of the L. G. A. The 7 communities that make up L. G. A includes; Omor, Umueje, Omasi, Igbakwu, Umumbo, Anaku, and Ifite-Ogwari with a population of 158,152 [23]. Ayamelum is situated between Latitudes $6^{\circ}$ 54'.95" N and Longitude 6 ${ }^{\circ} 99^{\prime} .38^{\prime \prime}$ E, with an estimated land area of $598 \mathrm{~km}^{2}$ and density of $355.4 / \mathrm{km}^{2}$.

Sampling Procedure and Method of Data Collection

The list of rice farmers in the L. G. A. was obtained from Anambra State Agricultural Development Programme (ASADP) Office which comprises of 2558 (1450 male and 1108 female) registered rice farmers. 100 farmers were randomly selected from the sample frame as the study representative. A multi-stage sampling technique was used to collect data from the 100 rice farmers separated by 70 rainfed and 30 dry seasons' rice farmers.

Stage one: 2 villages were randomly selected from each of the 7 communities in the study area to make it 14 villages. Stage two: 5 rice farmers were randomly sampled from the 14 villages to make it a total of 70 rain-fed rice farmers. Also, 3 communities (Omor, Umumbo and Anaku) were purposely selected in the fourth stage because of the presence of irrigation facilities like the Anaku-ude spring that cut across the 3 selected communities and World Bank Lower Irrigation Basin in the area. Furthermore, 2 villages were randomly selected to make it a total of 6 villages. Finally, 5 dry season rice farmers were randomly sampled to make it a total of 30 dry season rice farmers for the study.

\section{Method of Data Analysis}

Multiple regression analysis and principal factor analysis were the statistical tools used for the study. Objective 1 was achieved with multiple regression analysis, while objective 2 was achieved with the principal factor analysis. Thus, the model is stated as:

A) The implicit form of the multiple regression model is stated as:

$$
\mathrm{Y}=f\left(\mathrm{X}_{1}, \mathrm{X}_{2}, \mathrm{X}_{3}, \mathrm{X}_{4}, \mathrm{X}_{5}, \mathrm{X}_{6}, \mathrm{X}_{7}, \mathrm{e}\right)
$$

Where:

$\mathrm{Y}=$ yield $(\mathrm{kg})$

$$
f=\text { Function }
$$

$\mathrm{X}_{1}=$ Fertilizer $(\mathrm{kg})$

$\mathrm{X}_{2}=$ Urea $(\mathrm{kg})$

$\mathrm{X}_{3}=\operatorname{seed}(\mathrm{kg})$

$\mathrm{X}_{4}=$ Agro-chemical (liter)

$\mathrm{X}_{5}=$ labour (man-day) 
$\mathrm{X}_{6}=$ farm size (ha)

$\mathrm{X}_{7}=$ farming experience (years)

$\mathrm{X}_{8}=$ level of education (years)

$\mathrm{X}_{9}=$ number of extension visits (No), and

$\mathrm{e}=$ error term.

The four functional forms of Linear, Exponential, Semi$\log$, and Double-log were tried and the lead equation was selected based on the functional form with the highest $\mathrm{R}^{2}$, the highest number of significant variable (t-ratio), highest $\mathrm{F}$ stat, and in conformity with the a priori expectation. Thus, the explicit form of the model is stated below as;

Linear form:

$$
L=\beta_{0}+\beta_{1} X_{1}+\beta_{2} X_{2} \ldots \beta_{7} X_{7}+e(2)
$$

Exponential form:

$$
\operatorname{LnL}=\beta_{0}+\beta_{1} X_{1}+\beta_{2} X_{2} \ldots \beta_{7} X_{7}+e(3)
$$

Semi-log form:

$$
\mathrm{L}=\beta_{0}+\beta_{1} \operatorname{LnX}_{1}+\beta_{2} \operatorname{LnX}_{2} \ldots \beta_{7} \operatorname{LnX} X_{7}+\mathrm{e}(4)
$$

Double-log form (Cobb Douglas):

$$
\operatorname{LnL}=\beta_{0}+\beta_{1} \operatorname{LnX} 1+\beta_{2} \operatorname{LnX}_{2} \ldots \beta_{7} \operatorname{LnX}_{7}+\mathrm{e}(5)
$$

B). the principal component factor analysis (PCFA) model for objective two was stated as:

$$
\mathrm{Xij}=\delta \mathrm{i} 1 \mathrm{Fi} 1+\delta \mathrm{i} 2 \mathrm{Fi} 2+. . \delta \mathrm{jmFiK}+\mathrm{eij}(6)
$$

Where:

$\mathrm{Xij}=$ observation on variable $\mathrm{Xj}$ for the ith sample number

$\mathrm{FiK}=$ score on factor $\mathrm{FK}(\mathrm{K}=1,2,3 \ldots \mathrm{m})$

$\mathrm{F} 1-\mathrm{Fm}=$ common factors

eij $=$ the value on the residual variable Ej for the ith sample number, and

$\delta \mathrm{ji} \ldots . . \delta \mathrm{jm}=$ factor loading (regression weight)

The associated assumption will be applied accordingly while the suitable number of factors will be subjectively selected based on a variable with a maximum rotation factor matrix (varimax) obtained using SPSS version 23.0 software. The explanatory techniques using principal component factor model with interactions and varimax rotation will be adopted.

\section{Results and Discussions}

Rice Farmer's Production Function at Rain-fed
The regression result of rice farmer's production function at rain-fed is presented in Table 1. The double-log function with the highest $\mathrm{R}^{2}(0.8951)$. F-stat. of $136.15^{* *}$, highest number of variable significance and in conformity with the apriori expectation was chosen as the lead equation. Thus: the production equation is stated as follows:

$\mathrm{LnY}=76.8056+0.4841 \mathrm{LnX} 1+0.6607 \mathrm{LnX} 2+$ $0.3325 \operatorname{LnX} 3+27.4882 \operatorname{LnX} 4-28.0080 \operatorname{LnX} 5+0.0328 \operatorname{LnX} 6$ $+0.1019 \operatorname{LnX} 7+0.0235 \operatorname{LnX} 8-0.0719 \operatorname{LnX} 9$

The coefficient of Multiple Determinant $R^{2}$ (0.8951) indicates that $89.51 \%$ of the variation in rice output was explained by the joint actions of the exogenous variable (production input), while the remaining $10.49 \%$ was as a result of error beyond the control of the rice farmers.

The coefficient of seed, farm size, farming experience, level of education, and extension contact were not significant at either $5 \%$ or $1 \%$ level of probability. Therefore was not in agreement with reference 11 and 18 assertions.

The coefficient of Fertilizer was positive and significant at $1 \%$ level of probability, implying that a unit increase in the quantity of fertilizer used by the farmers will increase rice output by $0.4841 \mathrm{~kg}$. By a-priori expectation, the use of fertilizer is expected to increase farmers output.

The coefficient of Urea was positive and significant at $1 \%$ level of probability. This, therefore, suggests that a unit increase in the quantity of urea used by the rice farmers will equally increase their output by $0.6607 \mathrm{~kg}$. Urea has about $46 \%$ Nitrogen composition which helps in seed formation, thus its contribution to farmers output was expected.

The coefficient of Agro-chemical was positive and significant at $1 \%$ level of probability. This is an indication that per liter increase in the quantity of Agro-chemical used by the farmers will increase their rice output by $27.4882 \mathrm{~kg}$ in the study area. This was equally expected because the use of agrochemical will help to reduce weed competition that directly reduces plants access to essential nutrients necessary for seed formation and vegetation.

The coefficient of Labour was negative and significant at $1 \%$ level of probability. This is an indication that diminishing return has set in. continued labour supply on a fixed factor of production (land) will cause idleness. Therefore, increasing the number of labour force hired to the farm by a unit will cause $28.0080 \mathrm{~kg}$ reduction in output. During rain-fed rice farming, farmers should be able to know the time to stop employing labour force on their farm.

Table 1. Regression Result of Rice Farmer's Production Function at Rain-fed.

\begin{tabular}{llll}
\hline Variable & Linear & Exponential & Semi-log \\
\hline Intercept & $413.300(0.35)$ & $534006.582(2.47)$ & $7.727(70.87)$ \\
Fertilizer (X1) & $15.249(6.07)^{* *}$ & $3693.631(2.85)^{*}$ & $0.0018(7.77)^{* *}$ \\
Urea (X2) & $87.087(5.56)^{* *}$ & $7465.319(3.66)^{* *}$ & $0.0079(5.48)^{* *}$ \\
Seed (X3) & $54.706(0.93)$ & $1760.063(0.17)$ & $0.0052(0.96)$ \\
Agro-Chemical (X4) & $9437.318(3.01)^{* *}$ & $212480.635(2.63)^{*}$ & $1.2901(4.46)^{* *}$ \\
Labour (X5) & $-750.260(-3.32)^{* *}$ & $-217162.041(-2.51)^{*}$ & $0.0984(-4.73)^{* *}$ \\
Farm size (X6) & $393.646(0.35)$ & $810.390(0.41)$ & $0.664(5.11)^{* *}$ \\
Farming experience (X7) & $37.375(0.66)$ & $-301.502(-0.38)$ & $0.333(0.44)$ \\
Education (X8) & $-18.540(-0.32)$ & $-858.697(-1.25)$ & $0.0158(3.02)^{* *}$ \\
Extension contact (X9) & $-376.332(-1.49)$ & $-1270.740(-1.80)$ & $0.0085(1.62)$ \\
\hline
\end{tabular}




\begin{tabular}{lllll}
\hline Variable & Linear & Exponential & Semi-log & Double-log \\
\hline $\mathrm{R}^{2}$ & 0.8243 & 0.7951 & 0.8465 & 0.895 \\
F-stat. & $81.44 * *$ & 56.91 & $118.03 * *$ & $136.15^{* *}$ \\
$\mathrm{n}$ & 70 & 70 & 70 & 70 \\
\hline
\end{tabular}

Source: Field Survey Data, September 2019. (*) Significant at 5\% and (**) significant at 1\% level of probability. The figure in parenthesis is the t-ratios.

Rice Farmer's Production Function at Dry Season

The regression result of rice farmer's production function at dry season is presented in Table 2. The linear function with the highest $\mathrm{R}^{2}(0.7999)$. F-stat. of $15,157.08^{* *}$, highest number of variable significant and in conformity with the apriori expectation was chosen as the lead equation. Thus: the production equation is stated as follows:

$\mathrm{Y}=51.8195+0.6045 \mathrm{X} 1+1.3665 \mathrm{X} 2+0.1979 \mathrm{X} 3+$ $6.9561 \mathrm{X} 4+39.4251 \mathrm{X} 5+250.3440 \mathrm{X} 6-1.2484 \mathrm{X} 7-$ $3.1831 \mathrm{X} 8-2.7982 \mathrm{X} 9$.

The coefficient of Multiple Determinant $R^{2}(0.7999)$ indicates that $79.99 \%$ of the variation in dry season rice output was explained by the joint actions of the explanatory variable (production inputs), while the remaining 20.01\% was as a result of error beyond the control of the rice farmers.

The coefficient of Fertilizer, Urea, Seed, Agro-Chemical, Farming experience, Education, and Extension contact was not significant at either $5 \%$ or $1 \%$ level of probability.
The coefficient of Labour was positive and significant at $1 \%$ level of probability, this implies that increasing the number of labour supplied to the farm in dry season rice farming by a unit will increase the farmer's output by $39.43 \mathrm{~kg}$. Rice farming during the dry season requires more labour especially in the area of bird scaring than that of rain-fed rice farming. This is because only a few farmers are engaged in rice farming at this time with more pest, rodent among others to feast on the available rice farm.

The coefficient of Farm size was positive and significant at $1 \%$ level of probability, this implies that a unit increase in the number of hectares cultivated will equally increase farmer's rice output in the dry season by $250.34 \mathrm{~kg}$. During dry season rice farming, all the atmospheric condition favouring rice farming like photosynthesis, water availability/supply among other factors could be controlled to suit the farmer's test. Thus, more yield is expected during dry season rice farming than that of rain-fed rice farming.

Table 2. Regression Result of Rice Farmer's Production Function at Dry Season.

\begin{tabular}{|c|c|c|c|c|}
\hline Variable & Linear & Exponential & Semi-log & Double-log \\
\hline Intercept & $51.820(0.87)$ & $-43868.755(-4.51)$ & $7.361(40.26)$ & $4.157(35.79)$ \\
\hline Fertilizer (X1) & $0.605(0.76)$ & $-784.305(-0.30)$ & $0.002(0.85)$ & $0.018(0.57)$ \\
\hline Urea $(\mathrm{X} 2)$ & $1.367(0.57)$ & $2458.061(0.68)$ & $-0.004(-0.61)$ & $0.022(0.50)$ \\
\hline Agro-Chemical (X4) & $6.956(0.35)$ & $86.903(0.03)$ & $0.007(0.12)$ & $0.011(0.36)$ \\
\hline Labour (X5) & $39.425(16.09)^{* *}$ & $31229.782(4.61)^{* *}$ & $-0.003(-0.42)$ & $0.878(10.86)^{* *}$ \\
\hline Farm size $(\mathrm{X} 6)$ & $250.344(4.19)^{* *}$ & $-685.538(-0.49)$ & $0.051(0.28)$ & $0.065(3.89)^{* *}$ \\
\hline Education (X8) & $-3.183(-1.19)$ & $282.495(0.62)$ & $-0.008(-0.98)$ & $-0.007(-1.21)$ \\
\hline Extension contact (X9) & $-2.798(-0.27)$ & $-661.706(-1.59)$ & $0.077(2.44)^{*}$ & $-0.001(-0.26)$ \\
\hline $\mathrm{R}^{2}$ & 0.7999 & 0.7591 & 0.7346 & 0.7997 \\
\hline F-stat. & $15,157.08 * *$ & $52.08 * *$ & $31.75 * *$ & $8,036.36^{* *}$ \\
\hline $\mathrm{n}$ & 30 & 30 & 30 & 30 \\
\hline
\end{tabular}

Source: Field Survey Data, September 2019. (*) Significant at $5 \%$ and $(* *)$ significant at $1 \%$ level of probability. The figure in parenthesis is the t-ratios.

Furthermore, Table 3 shows the variables that are determinants of rice farming for the rain-fed and dry season rice farming in Ayamelum Local Government Area of Anambra State, Nigeria.

Table 3. Rain-fed and Dry Season Rice Farming Determinants in the Study Area.

\begin{tabular}{lll}
\hline Serial No. & Rain-fed Determinants & Dry Season Determinants \\
\hline 1 & Fertilizer $(\mathrm{kg})$ & Labour (man-day) \\
2 & Urea (kg) & Farm size (ha) \\
3 & Labour (man-day) & \\
4 & Agro-chemical (lt) & \\
\hline
\end{tabular}

Source: Field Survey Data, September 2019.

Challenges faced by Rain-fed and Dry Season Rice Farmers in Ayamelum Local Government Area.

The challenges faced by rice farmers in any of the production seasons are presented in Table 4. Kaiser-Meyer-
Olkin measure of sampling adequacy was significant at a probability level of 0.05 for both season and the Kaiser Normalization. The rotation converged in 5 iterations for both seasons. Eigen Value $>0.5$ indicates the major significant principal challenges rice farmers face in the area. The factors rotated in the model to ascertain the challenges rice farmers face at both main-season and dry season farming were categorized into three (3) component factors. Based on the rotation matrix with the strongest positive and negative correlation, factor 1 (Environmental) accounted for $21.42 \%$ and $21.79 \%$ of the variance of factors challenging rice farming at rain-fed and dry season in the study area respectively. Factor 2 (Institutional) accounted for 15.34\% and $17.90 \%$ of the variance of factors challenging rice farming at rain-fed and dry season in the study area respectively, and factor 3 (Economic) accounted for $13.51 \%$ and $14.37 \%$ of the variance of factors challenging rice farming at rain-fed and dry season in the study area 
respectively. The three factors explained $50.28 \%$ and $54.06 \%$ of the variance of the challenges confronting rice farmers at rain-fed and dry season respectively. Thus, the variables that made up the factors for rain-fed rice farming includes;

Environmental factors include the scarcity of labour, drought, increased bird attack, and cattle menace.

Institutional factors include a high incidence of pest and diseases, lack of market for the produce and high cost of labour.

Economic factors include: the high cost of input, flood, control of water is expensive, competition, expensive water pumping equipment, and poorly developed irrigation facility. While on the other hand. The variables that made up the dry season factors include;

Environmental factors: the scarcity of labour, flood, drought, control of water is expensive, high cost of labour, cattle menace.

Institutional factors: increased bird attack, competition, and poorly developed irrigation facility.

Economic factors include the high cost of input, high incidence of pest and diseases, lack of market for the produce, and expensive water pumping equipment.

Table 4. Challenges faced by Rain-fed and Dry Season Rice Farmers in Ayamelum Local Government Area.

\begin{tabular}{|c|c|c|c|c|c|c|c|}
\hline \multirow{2}{*}{ Sn } & \multirow{2}{*}{ Challenges } & \multicolumn{3}{|c|}{ Main season component seasons } & \multicolumn{3}{|c|}{ Dry season component matrix ${ }^{a}$} \\
\hline & & Factor 1 & Factor 2 & Factor 3 & Factor 1 & Factor 2 & Factors 3 \\
\hline 1 & Scarcity of labour & 0.651 & 0.494 & -0.066 & 0.737 & 0.104 & -0.041 \\
\hline 2 & High cost of input & 0.384 & 0.334 & -0.492 & 0.282 & 0.014 & 0.628 \\
\hline 3 & Flood & 0.174 & 0.004 & -0.226 & 0.591 & 0.584 & 0.176 \\
\hline 4 & Drought & 0.862 & 0.125 & -0.067 & 0.304 & -0.122 & 0.236 \\
\hline 5 & High incidence of pest and diseases & 0.348 & -0.759 & -0.028 & -0.153 & 0.171 & -0.482 \\
\hline 6 & Increased bird attack & 0.760 & -0.284 & 0.040 & 0.188 & 0.862 & -0.114 \\
\hline 7 & Control of water is expensive & 0.129 & 0.027 & 0.674 & -0.633 & 0.197 & 0.380 \\
\hline 8 & Lack of market for the produce & -0.043 & 0.689 & 0.074 & -0.258 & 0.044 & 0.647 \\
\hline 9 & Competition & -0.035 & 0.026 & 0.811 & -0.299 & 0.624 & -0.195 \\
\hline 10 & High cost of labour & 0.137 & 0.650 & -0.039 & 0.671 & 0.178 & 0.135 \\
\hline 11 & Cattle menace & -0.596 & 0.087 & -0.032 & 0.687 & -0.133 & 0.097 \\
\hline 12 & Expensive water pumping equipment & -0.307 & -0.275 & 0.518 & -0.010 & 0.201 & 0.832 \\
\hline 13 & Poor developed irrigation facility & -0.159 & -0.163 & -0.499 & -0.040 & 0.760 & 0.375 \\
\hline
\end{tabular}

Source: Field Survey Data, September 2019.

\section{Conclusion}

One of the measures to ensure food security in a nation involves all year round production. Rice demand in Nigeria is attributed to population increase which in turn will require an increase in cultivable land area for rice. Apart from making a profit, rice farmers should see it as their responsibility to create job while supplying the nation's food basket with enough rice. The results produced in this study is found to be in consonance with the reviewed literature. Therefore the study made it evident that rain-fed rice farming in the study area is dependent on fertilizer, urea and agro-chemical. On the other hand, dry season rice farming in the study area is equally dependent on labour supply and farm size. This farm size justified the demand for labour more by the farmers in the area. One should not also play a blind eye to the grey areas that challenge rice farming at both rainfed and dry season, thus, these challenges were named in three factors (environmental, institutional and economic) by the researcher. Since the environmental factors accounted for more variation in the challenges faced by the farmers for both rain-fed and dry season, the researcher, therefore, recommends that;

a) Bird scaring equipment should be made available for the farmers to reduce the lose encountered by the rice farmers

b) Machinery should be made available to the farmers to reduce the cost incurred on hired labour that reduced the farmer's profit.

c) There is an urgent need to address herds-farmers conflict that scares farmers from going fully into rice farming for both seasons. Thus, a conflict resolution committee should be constituted to solve their disagreement.

\section{References}

[1] E. Y. Ngaltungo (2015). Comparative economic analysis of upland and lowland rainfed rice production in selected local government areas of Kaduna State, Nigeria. An unpublished thesis submitted to the Department of Agricultural Economics and Rural Sociology, Ahmadu Bello University, Zaria, Nigeria. Pp: 142.

[2] J. C. Norman and B. Kebe (2004). African smallholder farmers: rice production and sustainable livelihoods. Regional perspectives. Pp $33-58$

[3] T. M. Kudi, R. Yakubu and D. H. Nasa'l (2010). Comparative analysis of the profitability of NERICA rice and local rice varieties production in Chukun Local Government Area of Kaduna State, Nigeria. Journal of Agriculture and Social Research 10 (2): $67-72$.

[4] FAOSTAT, (2010). Food and Agricultural Organization Statistics. Food and Agricultural Organization (FAO). Retrieved October 26, 2019, from http://www.faostat.org/site/342/default.aspx.

[5] CBN (2012). Demand for rice in Nigeria, CBN annual report. Central Bank of Nigeria (CBN) Abuja. pp 50-54. 
[6] Agricultural Transformation Agenda (ATA) (2010). Rice transformation project proposal report submitted to the Federal Ministry of Agriculture and Rural Development, Abuja Nigeria.

[7] FAOSTAT (2013). Food and Agricultural Organization Statistics. Food and Agricultural Organization (FAO), Retrieved October 26, 2019, from http://www.faostat.org/site/567/default.aspx.

[8] RIMIDAN (2017). Nigeria cannot attain self-sufficiency in rice production by 2018. S. Foyeku (Eds.). Rice Importers, Millers and Distribution Association of Nigeria. Retrieved online, January 12, 2019, from www.shipandport.com.

[9] C. A. Obianefo, N. F. Aguaguiyi, E. E. Umebali and C. I. Ezeano (2019). Comparative analysis of rain-fed and dry season rice farming in Value Chain Development Programme in Ayamelum Local Government Area- Anambra State. International Journal of Science and Research. 8 (7), pp: 16551659. DOI: $10.21275 / \operatorname{art} 20198913$.

[10] USDA (2014): Agricultural Statistic. U.S. Government. United State Department of Agriculture. Washington. Printing Office. DC Area (202) 512-1800.

[11] C. U. Onugu, C. A Obianefo and N. L. Anumba (2018). Constraints to adoption of good agronomic practice among rice farmers in Anambra State Value Chain Development Programme. Proceedings of the 2nd International Conference on Food Security and Hidden Hunger 8th $-10^{\text {th }}$ October 2018, Alex Ekwueme Federal University Ndufu-Alike, faculty of Agriculture. Pp 55-61.

[12] G. Makombe, R. NAMARA, F. HAGOS, S. B. AWULACHEW, M. AYANA, and D. BOSSIO (2011). A comparative analysis of the technical efficiency of rain-fed and smallholder irrigation in Ethiopia, Vol. Iwmi Working Paper 143. Colombo, Sri Lanka, International Water Management Institute.

[13] R. O. Babatunde, M. F. Salami and B. A. Mohammed (2016). Determinants of yield gap in rain-fed and irrigated rice production: Evidence from a household survey in Kwara State. Proceeding of the 5th International Conference of the African Association of Agricultural Economists, September 23-26, 2016, Addis Ababa, Ethiopia. Pp: 9.

[14] T. A. Manoj and B. W. Mugera (2013). Production efficiency and technology gap in irrigated and rain-fed rice farming systems in Sri Lanka: Non parametric approach. Australian Agricultural and Resource Economics Society. School of
Agricultural and Resource Economics, University of Western Australia m089, 35 Stirling Highway, Crawley Wa 6009 Australia, Tel: +61-08-6488-4633, fax: +61-08-6488-1098. pp: 27. https://www.researchgate.net/publication/253239077 producti on_efficiency_and_technology_gap_in_irrigated_and_rainfed_rice_farming_systems_in_sri_lanka_non_parametric_appr oach [accessed Oct. 26 2019].

[15] S. Nkwazema (2016, November 5) - THISDAYLIVE. The Rice Debate: Why Nigeria Can't Meet Local Rice Production Demand. Retrieved 12 March 2019 from https://www.thisdaylive.com/index.php/2016/11/05/the-ricedebate-why-nigeria-cant-meet-local-rice-production-demand/.

[16] B. B. Wategire and P. C. Ike (2015). An analysis of the Technical Efficiency of non-motorized small scale Shrimp Fishers in the Coastal areas of Delta State, Nigeria. Mediterranean Journal of Social Sciences. 6 (1), pp: 285-291. DOI: $10.5901 / \mathrm{mjss} .2015 . v 6 n 1 \mathrm{p} 285$.

[17] H. E. Tilahun, M. M. Teklu, and S. B. Awulachew (2011). Comparative performance of irrigated and rain-fed agriculture in Ethiopia. World Applied Sciences Journal 14 (2): 235-244.

[18] J. A. Olufemi (2016). Economic analysis of irrigated rice production in Kura Local Government Area of Kano State, Nigeria. A thesis submitted to the Department of Agricultural Economics and Rural Sociology, Ahmadu Bello University Zaria, Nigeria. Pp: 82.

[19] O. W. Osawe, V. O. Akinyosoye, B. T. Omonona, V. O. Okoruwa and K. K. Salman (2017). Productivity differentials in rice production systems: Evidence from rice farmers in five Agro-ecological Zones in Nigeria. J. Nutraceuticals Food Sci. Vol. 2 No. 3: 18-27.

[20] A. Sani, A. A. Yakubu and H. M. Bello (2010). Resource-use efficiency in rice production under small scale irrigation in bunkure local government area of kano state, nigerian journal of basic and applied science. 18 (2): 292-296.

[21] A. Abdul-Gafar, S. W. Xu, Y. Wen and W. Yu (2017). Comparative study on factors influencing rice yield in Niger state of Nigeria and Hainan of China. International Journal of Agricultural and Food Research. Vol. 6 No. 1, pp. 15-25.

[22] A. Ahmed, S. Xu, W. Yu, Y. Wang (2017). Comparative study on factors influencing rice yield in Niger State of Nigeria and Hainan of China. Int. J. Agric. Food Res. 6 (1): 15-25.

[23] NPC (2006). National Population Census results. Federal Government of Nigeria Official gazette 24, (94): 6-7. 